\title{
Portfolio of Beetroot (Beta vulgaris L.) Peel Extracts Concentrated by Nanofiltration Membrane
}

\author{
MoH MoH ZIN ${ }^{a^{*}}$ AND SzILvia BÁNVÖLGYI ${ }^{\mathrm{a}}$ \\ ${ }^{a}$ Department of Food Engineering, Hungarian University of Agriculture and Life Sciences, Budapest, Hungary \\ ${ }^{*}$ Corresponding author \\ zinlay.net.mm@gmail.com \\ TEL: +36702848794
}

Received: 26 April 2020; Published online: 18 October 2021

Check for updates

\begin{abstract}
Membrane process is an intelligent alternative way of concentration, preferably for organic juices rich in thermolabile natural components. The expectation is to scale up the extraction of desired compounds from agro-industrial wastes through modernized concentration methods. Recovery of betalains, phenolic, and antioxidant from beetroot peel extracts was accomplished by nanofiltration membrane (NF 200) at a recirculation flow rate $\left(400 \mathrm{~L} \mathrm{~h}^{-1}\right)$ and feed temperature $\left(30{ }^{\circ} \mathrm{C}\right)$ under constant transmembrane pressure (40 bar). Characterization of betaxanthin, betacyanin, phenolic, and antioxidant activity by spectrophotometric analysis revealed that the final samples contain these compounds respectively: $202.25 \pm 3.26 \mathrm{mg} \cdot \mathrm{L}^{-1}, 360.07 \pm 8.43 \mathrm{mg} \cdot \mathrm{L}^{-1}, 987.79 \pm 19.18 \mathrm{mg} \cdot \mathrm{L}^{-1}, 642.06 \pm 14.78$ $\mathrm{mg} \cdot \mathrm{L}^{-1}$ (pure water); $206.62 \pm 1.37 \mathrm{mg} \cdot \mathrm{L}^{-1}, 339.72 \pm 2.89 \mathrm{mg} \cdot \mathrm{L}^{-1}, 972.72 \pm 47.49 \mathrm{mg} \cdot \mathrm{L}^{-1}, 745.97 \pm 25.45$ $\mathrm{mg} \cdot \mathrm{L}^{-1}$ (ethanol-water). Final samples exhibit vivid colour and a considerably large amount of desired compounds compared to crude extracts and could have industrial applications.
\end{abstract}

Keywords: Beetroot; Betalains; Phenolic; Antioxidant; Nanofiltration

\section{Introduction}

Agro-industrial residues, including beetroot peel, are acknowledged sources of antioxidant-rich compounds such as betalains and phenolic compounds. To maximize the recovery of these valuable compounds with minimal processing cost and utilize them in various fields is quite challenging because of their ease of compartmentalization. Beetroot, a typically known source of betalains and phytochemicals, is rich in therapeutic values and minerals, thereby getting many compliments from consumers as well as food researchers. As stated by Kale et al. (2018), beetroot is a chief source of several macro and micronutrients, for example, carbohydrate (7.59 $\%)$, protein $(1.35 \%)$, sodium and potassium (72.58 and $30.12 \mathrm{mg} / 100 \mathrm{~g}$ of beetroot), and betalain (14.2 mg/ $100 \mathrm{~g}$ of beetroot).

Betalain is an active hydrophilic compound mainly found in species of Caryophyllales plant families (Hussain et al., 2018). Determined by the components attached to the main structure of betalamic acid (4-[2-oxoethylidene]-1,2,3,4tetrahydropyridene-2,6-dicarboxylic acid), two structural groups known as betaxanthin and betacyanin are derived. Vulgaxanthin-I (80 \% of betaxanthin), a derivative of betalamic acid conjugated with amines, is responsible for its yellow colour (Sawicki \& Wiczkowski, 2018). Red-violet is the predominant colour of betanin (69\% of betacyanin) which is derived from the condensation of betalamic acid with $3,4-$ dihydroxyphenylalanine or its glucosyl derivatives (Elbandy \& Abdelfadeil, 2008; Miguel, 


\section{Nomenclature}

$\Delta \mathrm{t}$ time required to collect the filtrate (h)

$\Delta \mathrm{V} \quad$ volume of filtrate (L)

A sample absorbance

AA antioxidant activity

AC antioxidant capacity (mg. $\mathrm{L}^{-1}$ )

$\mathrm{A}_{m} \quad$ active surface area of membrane $\left(\mathrm{m}^{2}\right)$

BC betacyanin

BX betaxanthin

$\mathrm{C}_{0} \quad$ concentration of initial feed $\left(\mathrm{mg} . \mathrm{L}^{-1}\right)$

$\mathrm{C}_{R} \quad$ concentration of retentate $\left(\mathrm{mg} . \mathrm{L}^{-1}\right)$

DF dilution factor

EWE ethanol-water extract

FRAP ferric reducing antioxidant power

$\mathrm{J} \quad$ permeate flux of pure water $\left(\mathrm{m}^{3} /\left(\mathrm{m}^{2}\right.\right.$. s))

$\mathrm{J}_{x} \quad$ permeate flux of sample $\left(\mathrm{L} /\left(\mathrm{m}^{2} \cdot \mathrm{h}\right)\right)$
L path length $(\mathrm{cm})$

MW molecular weight $(\mathrm{g} / \mathrm{mol})$

$\mathrm{R}_{m} \quad$ membrane resistance $(1 / \mathrm{m})$

$\mathrm{S} \quad$ amount of sample $(\mu \mathrm{L})$

TMP applied transmembrane pressure difference $(\mathrm{Pa})$

TPC concentration of total phenolic compounds $\left(\mathrm{mg} . \mathrm{L}^{-1}\right)$

VRR volume reduction ratio

WE water extract

$\alpha_{1} \quad$ slope of TPC calibration curve

$\alpha_{2} \quad$ slope of AA calibration curve

$\mu \quad$ dynamic viscosity of permeate $(\mathrm{Pa} \cdot \mathrm{s})$

$\varepsilon \quad$ molar extinction coefficient $(\mathrm{L} /(\mathrm{mol}$. $\mathrm{cm})$ )
2018; Sawicki \& Wiczkowski, 2018). Phenolic compounds found in fruits and vegetables are in the range of simple phenolic acids to complex forms and exhibit antiradical activity to some degree according to their hydroxyl group structures (Shahidi \& Ambigaipalan, 2015). As both betalains and phenolics are plant secondary metabolites condensed with antiradical scavenging property (Bucur et al., 2016; Kavalcová et al., 2015), they can defend against oxidative stress and related chronic diseases such as cancer, cardiovascular disease, and neurodegenerative disorders like Parkinson's and Alzheimer's (Mironczuk-Chodakowska et al., 2018).

Membrane filtration is a promising technology with high throughput and low cost if properly applied. Its benefit in biological separation has been known by scientists for decades but it is not quite commonly used. Lately, the trend of modern separation and purification technology brings its application back with some improvements; especially in food processing industries with the purposes of concentration and clarification of beverages including red wine (Banvolgyi et al., 2006), blackcurrant juice (Banvolgyi et al., 2009), apple juice (Vladisavljevic et al., 2003), strawberry juice (Arend et al., 2017), and Indian blackberry juice (Ghosh et al., 2018). Polymeric membranes have low thermal conductivity and high resistance to almost all organic solvents at processing temperatures (Perfilov, 2018). Pressure driven nanofiltration membrane has a higher retention rate of particles with molecular weight between 100 and 1000 Da (Dach, 2008). In addition, nanofiltration is a globally used membrane technology not only for lone filtration but also as a pretreatment for reverse osmosis feed.

Reusing agro-industrial waste products from food industries is one of the effective ways to save the planet by diminishing the waste of fruits and vegetables (dos Santos et al., 2016). Recovery of bioactive compounds from the waste parts of the beetroots, stalk (Maran \& Priya, 2016), peel (Kujala et al., 2001; Sawicki et al., 2016; Zin et 
al., 2020), and pomace (Vulic et al., 2013), has been accomplished through solid-liquid based extraction methods. Notwithstanding, clarification of beetroot (stalk) extracts has been successfully realized via different membrane filtration processes such as microfiltration and ultrafiltration (dos Santos et al., 2016).

Beetroot peel got our attention for this work as betalain content in the peel is high (Sawicki et al., 2016; Zin et al., 2020). Based on the molecular weight of the targeted compounds, nanofiltration membrane was chosen. The aim of this study was to determine how many levels of nanofiltration concentration could be attained for beetroot peel extracts while ascertaining the reduction in volume. Furthermore, the synergistic effects between betalains, phenolic compounds and antioxidant activity were also explored.

\section{Materials and Methods}

\subsection{Extraction of Beetroot Peel Juice}

Beetroots (Beta vulgaris L.) were procured from a local market in Hungary and processed right away for extraction. Extraction was accomplished by a single batch type mode at a processing temperature of $22^{\circ} \mathrm{C}$ for 60 minutes with pure water and $15 \%(\mathrm{v} / \mathrm{v})$ aqueous ethanol solvent (1:10 peel-to-solvent ratio).

\subsection{Membrane Processing}

Crossflow filtration process was accomplished by Polyamide Thin Film Composite (NF 200, FILMTEC $^{T M}$ Membrane) using DDS Filtration Equipment (LAB 20-0.72, Denmark). The parameters were as follows: operation temperature $\left(30{ }^{\circ} \mathrm{C}\right)$, transmembrane pressure (TMP, average $40 \mathrm{bar})$, and recirculation flow rate $(400 \mathrm{~L} / \mathrm{h})$ (Figure 1). Concentrated samples were collected from the tank every $500 \mathrm{~mL}$ interval of permeate and the time taken to reach each $100 \mathrm{~mL}$ of permeate was recorded for future calculation. According to Darcy's law, the flux of pure water $\mathrm{J}\left(\mathrm{m}^{3} /\left(\mathrm{m}^{2} \cdot \mathrm{s}\right)\right)$ passing through any type of membrane can be estimated by TMP (Pa) applied for the operation divided by the resistance of the membrane, $\mathrm{R}_{m}\left(\mathrm{~m}^{-1}\right)$ and the dynamic viscosity of the permeate, $\mu(\mathrm{Pa} \cdot \mathrm{s})$ (equation 1 ) (Miller et al., 2014).

$$
J=\frac{T M P}{\mu \times R_{m}}
$$

Dach (2008) defined volumetric flux $\left(\mathrm{J}_{x}\right)$ as the measured volume of permeate at a given time interval. In this experiment, the permeate flux $\left(\mathrm{L} /\left(\mathrm{m}^{2} \cdot \mathrm{h}\right)\right)$ of the sample was determined from direct measurement of filtrate volume, DeltaV (L), divided by the time required to collect the filtrate, $\Delta \mathrm{t}(\mathrm{h})$, and total active surface area of membrane, $\mathrm{A}_{m}\left(\mathrm{~m}^{2}\right)$ as expressed in equation (2) (Liu et al., 2011).

$$
J_{x}=\frac{\Delta V}{A_{m} \times \Delta t}
$$

\subsection{Spectrophotometry Analysis}

Centrifugation of the extracts was conducted before spectrophotometric analysis. Determination of desired compound quantity was executed by spectrophotometer (Genesys 5 UV-visible, MILTON ROY, U.S.A) with appropriate dilution. For colour compound detection, absorbance measurements were at $470 \mathrm{~nm}$ for betaxanthin compound (vulgaxanthin-I) and $538 \mathrm{~nm}$ for betacyanin compound (betanin); and quantified according to equation (3) (Chong et al., 2014; Nemzer et al., 2011).

$$
\text { Betalain }=\frac{A \times M W \times D F \times 1000}{\varepsilon \times L} \times\left(m g . L^{-1}\right)
$$

Where A is the absorbance; MW is the molecular weight $(\mathrm{g} / \mathrm{mol})$; $\mathrm{DF}$ is the dilution factor; $\varepsilon$ is the molar extinction coefficient $(\mathrm{L} /(\mathrm{mol} \cdot \mathrm{cm}))$ and $\mathrm{L}$ is the path length $(\mathrm{cm})$. Molecular weights and molar extinction coefficients for each betaxanthin and betacyanin are as follow: $\mathrm{MW}=308$ $\mathrm{g} / \mathrm{mol}$ and $550 \mathrm{~g} / \mathrm{mol} ; \varepsilon=48,000 \mathrm{~L} /(\mathrm{mol} \cdot \mathrm{cm})$ and $60,000 \mathrm{~L} /(\mathrm{mol} \cdot \mathrm{cm})$. Quantification of total phenolic compound contents of each sample was completed by the Folin-Ciocalteu colourimetric method at $760 \mathrm{~nm}$ and calculated as expressed in equation (4):

$$
T P C=\frac{A \times 2500 \times D F}{S \times \alpha_{1}}\left[\frac{m g G A E}{L}\right]
$$


Beetroot Peel Extracts Concentrated by NF | 337

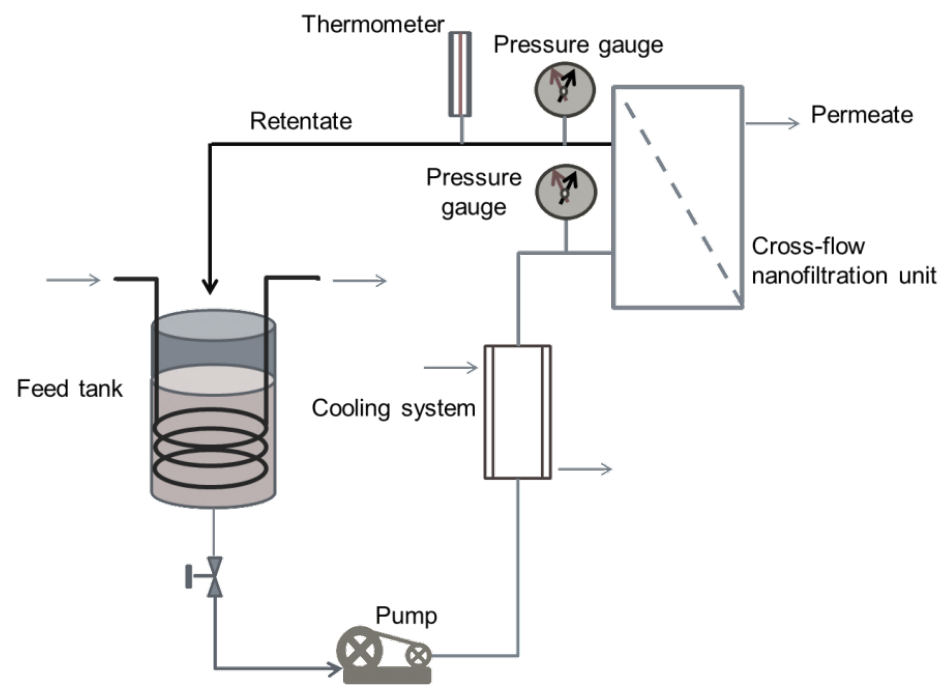

Figure 1: Scheme of cross-flow nanofiltration in batch mode

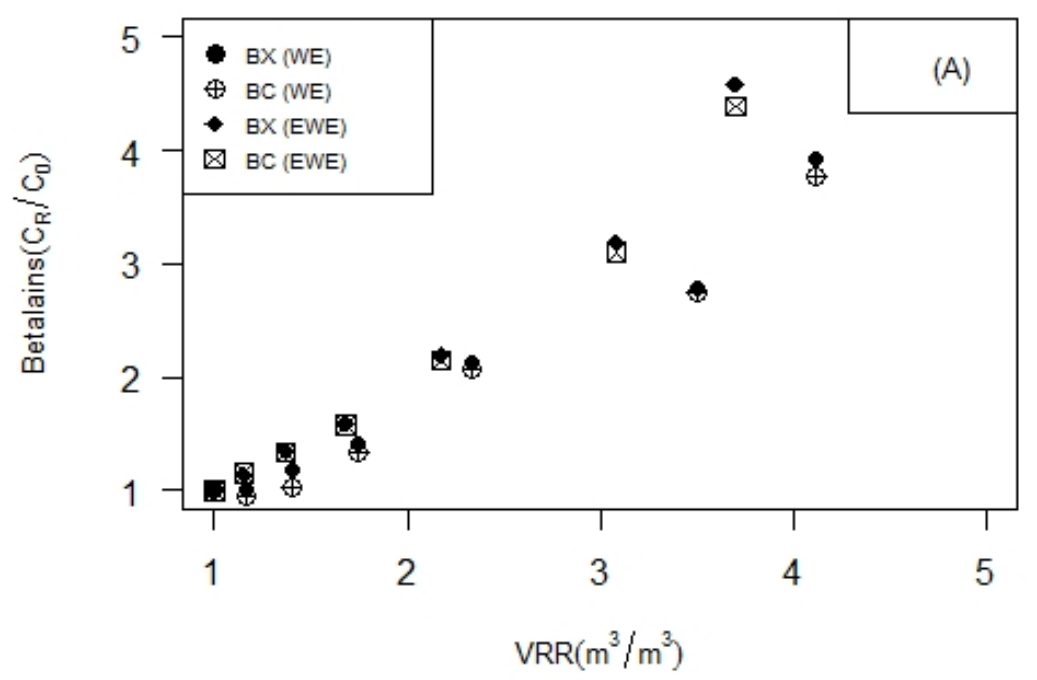

Figure 2: Concentration ratios $\left(\mathrm{C}_{R} / \mathrm{C}_{0}\right)$ of respective betalain compounds varied with the volume reduction ratio (VRR) 
$338 \mid$ Zin and Bánvölgyi

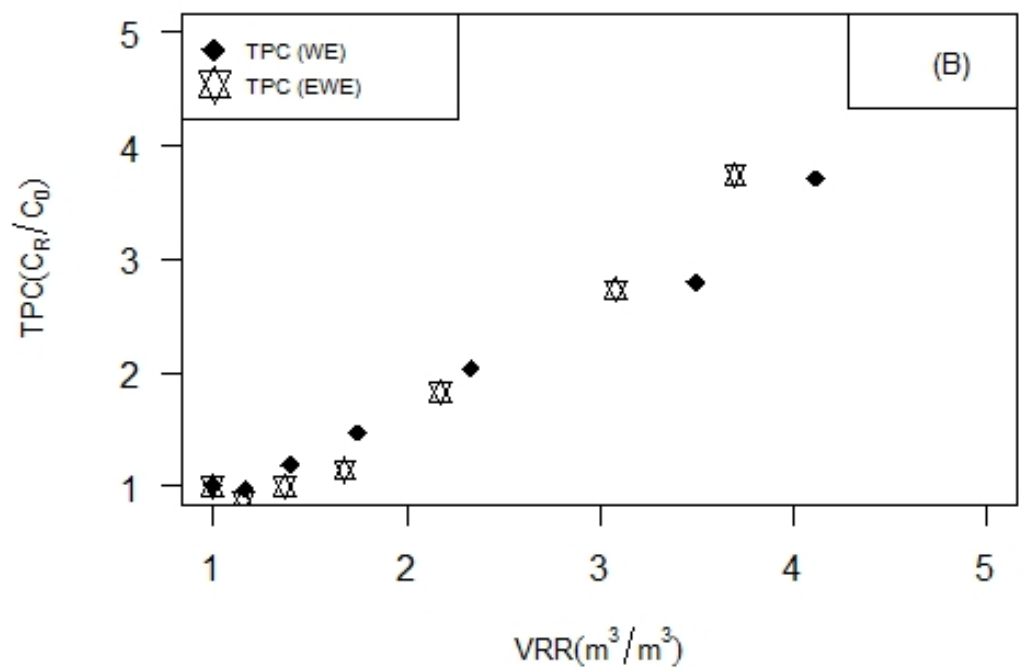

Figure 3: Changes in concentration ratios $\left(\mathrm{C}_{R} / \mathrm{C}_{0}\right)$ of phenolic compounds with volume reduction ratio (VRR)

Whereby $\mathrm{A}$ is the measured absorbance; DF is the dilution factor; $\mathrm{S}$ is the amount of sample $(\mu \mathrm{L}) ; \alpha_{1}$ is the slope of the calibration curve (Koczka et al., 2018). For the antioxidant activity (AA) assay, the ferric reducing antioxidant power (FRAP) method was applied, and the measurement was done at $593 \mathrm{~nm}$ (equation $5)$.

$$
A A=\frac{A \times 1550 \times D F}{S \times \alpha_{2}}\left[\frac{m g A S E}{L}\right]
$$

Where $\mathrm{A}$ is the absorbance; DF is the dilution factor; $\mathrm{S}$ is the amount of sample $(\mu \mathrm{L}) ; \alpha_{2}$ is the slope of the calibration curve (Benzie \& Strain, 1996). Data were evaluated by the performing variance analysis model using $\mathrm{R}$ statistic software (version 3.6.2). The concentration process of each extract was performed twice, and all sample analyses were performed in triplicate.

\section{Results and Discussion}

Extraction processes were determined based on our previous experiment in which optimization of the process conditions was focused on achieving the highest betalain compounds, except for peel-to-solvent ratio (Zin et al., 2020). Sample analysis was in triplicate in order to calculate mean values and standard deviations. Analysis of variance showed that a significant level (within and between groups) of all desired compounds was $99.99+\%(p$-value $<0.001)$. Table 1 represents the outcomes of the spectrophotometric analysis of betalains, phenolic, and antiradical activity. The amount of those respective compounds detected in water crude extract were as follows: $51.46 \pm 1.61 \mathrm{mg} \cdot \mathrm{L}^{-1}$ (betaxanthin), $95.29 \pm 0.58 \mathrm{mg} \cdot \mathrm{L}^{-1}$ (betacyanin), 265.96 \pm 3.42 $\mathrm{mg} \cdot \mathrm{L}^{-1}$ (phenolic), $250.40 \pm 27.34 \mathrm{mg} \cdot \mathrm{L}^{-1}$ (antiradical activity) but, their contents in aqueous ethanol crude extracts were a bit lower than the former: $45.05 \pm 1.17 \mathrm{mg} \cdot \mathrm{L}^{-1}$ (betaxanthin), $78.38 \pm 1.67 \mathrm{mg} \cdot \mathrm{L}^{-1}$ (betacyanin), $259.91 \pm 29.06$ 


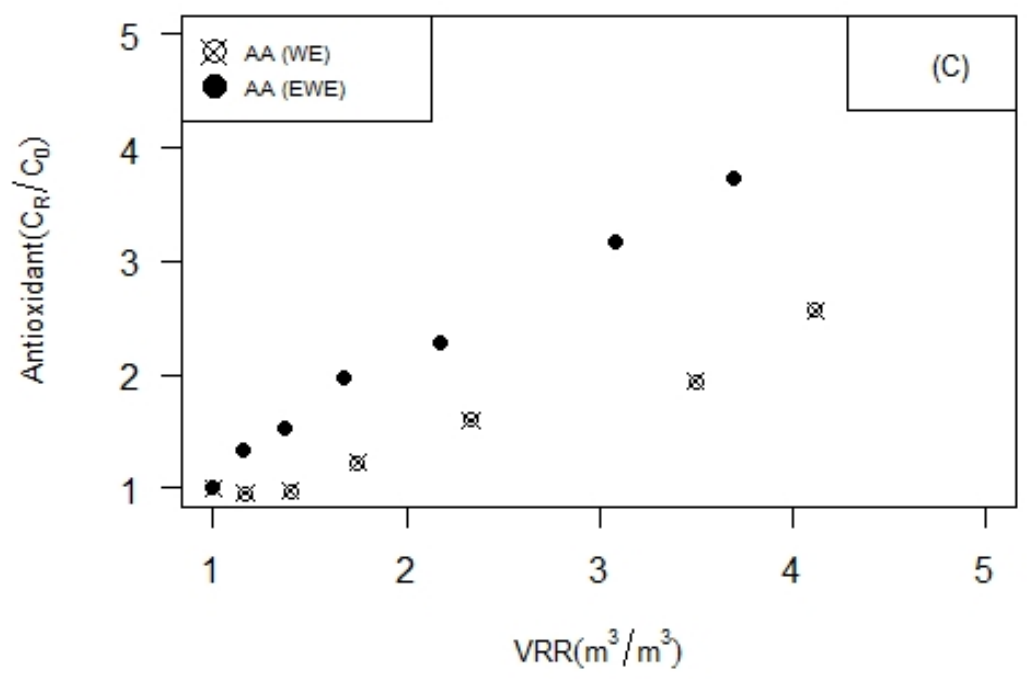

Figure 4: Changes in concentration ratios $\left(\mathrm{C}_{R} / \mathrm{C}_{0}\right)$ of antioxidant activity with volume reduction ratio $(\mathrm{VRR}))$

Table 1: Variation of betalains, phenolic contents, and antioxidant activity with volume

\begin{tabular}{|c|c|c|c|c|c|}
\hline & Sample & $\begin{array}{l}\text { Betaxanthin } \\
\left(\mathrm{mg} \cdot \mathrm{L}^{-1}\right)\end{array}$ & $\begin{array}{l}\text { Betacyanin } \\
\left(\mathrm{mg} \cdot \mathrm{L}^{-1}\right)\end{array}$ & $\begin{array}{c}\mathrm{TPC} \\
\left(\mathrm{mg} \cdot \mathrm{L}^{-1}\right)\end{array}$ & $\begin{array}{l}\text { Antioxidant Activity } \\
\left(\mathrm{mg} \cdot \mathrm{L}^{-1}\right)\end{array}$ \\
\hline \multirow{7}{*}{ 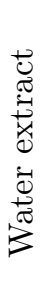 } & Initial feed & $51.46 \pm 1.61^{a}$ & $95.29 \pm 0.58^{a}$ & $265.96 \pm 3.42^{a}$ & $250.40 \pm 27.34^{a}$ \\
\hline & $\mathrm{R}(500 \mathrm{~mL})$ & $51.72 \pm 2.56^{a}$ & $91.03 \pm 0.39^{a}$ & $259.51 \pm 13.32^{a}$ & $238.01 \pm 6.03^{a}$ \\
\hline & $\mathrm{R}(1000 \mathrm{~mL})$ & $60.77 \pm 1.89^{a}$ & $98.36 \pm 1.36^{a}$ & $315.52 \pm 1.71^{a}$ & $242.79 \pm 2.3^{a}$ \\
\hline & $\mathrm{R}(1500 \mathrm{~mL})$ & $72.51 \pm 1.42^{a}$ & $127.42 \pm 2.06^{a}$ & $391.68 \pm 20.52^{a}$ & $305.94 \pm 27.09^{a}$ \\
\hline & $\mathrm{R}(2000 \mathrm{~mL})$ & $109.4 \pm 1.31^{a}$ & $197.82 \pm 4.16^{a}$ & $542.39 \pm 3.69^{a}$ & $401.14 \pm 22.17^{a}$ \\
\hline & $\mathrm{R}(2500 \mathrm{~mL})$ & $143.41 \pm 1.45^{a}$ & $261.62 \pm 2.75^{a}$ & $743.47 \pm 25.64^{a}$ & $485.99 \pm 0.00^{a}$ \\
\hline & Final & $202.25 \pm 3.26^{a}$ & $360.07 \pm 8.43^{a}$ & $987.79 \pm 19.18^{a}$ & $642.06 \pm 14.78^{a}$ \\
\hline \multirow{5}{*}{ 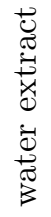 } & Initial feed & $45.05 \pm 1.17^{a}$ & $78.38 \pm 1.67^{a}$ & $259.91 \pm 29.06^{a}$ & $199.70 \pm 3.28^{a}$ \\
\hline & $\mathrm{R}(500 \mathrm{~mL})$ & $51.08 \pm 1.98^{a}$ & $89.56 \pm 2.34^{a}$ & $227.27 \pm 10.26^{a}$ & $266.46 \pm 12.31^{a}$ \\
\hline & $\mathrm{R}(1000 \mathrm{~mL})$ & $60.57 \pm 1.57^{a}$ & $103.22 \pm 2.94^{a}$ & $258.70 \pm 11.08^{a}$ & $305.36 \pm 8.21^{a}$ \\
\hline & $\mathrm{R}(1500 \mathrm{~mL})$ & $71.74 \pm 0.48^{a}$ & $122.1 \pm 1.8^{a}$ & $296.18 \pm 8.55^{a}$ & $394.08 \pm 15.01^{a}$ \\
\hline & $\mathrm{R}(2000 \mathrm{~mL})$ & $98.88 \pm 0.68^{a}$ & $166.47 \pm 2.5^{a}$ & $475.10 \pm 15.39^{a}$ & $456.29 \pm 8.21^{a}$ \\
\hline 1 & $\mathrm{R}(2500 \mathrm{~mL})$ & $143.48 \pm 1.93^{a}$ & $240.63 \pm 1.93^{a}$ & 709. $62 \pm 1.71^{a}$ & $634.51 \pm 2.46^{a}$ \\
\hline 牙 & Final & $206.62 \pm 1.37^{a}$ & $339.72 \pm 2.89^{a}$ & $972.72 \pm 47.49^{a}$ & $745.97 \pm 25.45^{a}$ \\
\hline
\end{tabular}

Different superscript letters mean significant differences $(p<0.001)$ 


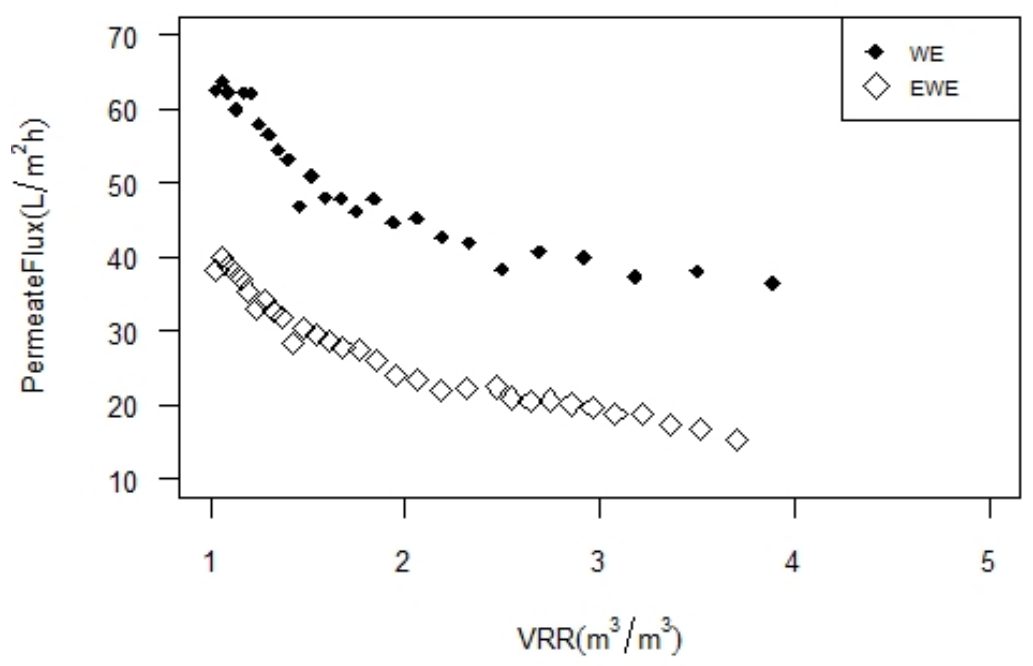

Figure 5: Variation of permeate flux values with volume reduction ratio (VRR) during the concentration process by nanomembrane type NF 200

Table 2: Correlation between the desired compounds and their antioxidant activity

\begin{tabular}{|c|c|c|c|}
\hline & Variables & Correlation & Regression Statistics \\
\hline \multirow{5}{*}{ 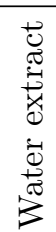 } & $\mathrm{AA} \& \mathrm{BX}^{a}$ & 0.99 & $\mathrm{R}^{2}=0.9948$ \\
\hline & $\mathrm{AA} \& \mathrm{BC}^{a}$ & 0.99 & $\mathrm{R}^{2}=0.9979$ \\
\hline & $\mathrm{AA} \& \mathrm{TPC}^{a}$ & 0.99 & $\mathrm{R}^{2}=0.9925$ \\
\hline & $\mathrm{TPC} \& \mathrm{BX}^{a}$ & 0.99 & $\mathrm{R}^{2}=0.9966$ \\
\hline & $\mathrm{TPC} \& \mathrm{BC}^{a}$ & 0.99 & $\mathrm{R}^{2}=0.9957$ \\
\hline \multirow{9}{*}{ 吉 } & $\mathrm{AA} \& \mathrm{BX}^{a}$ & 0.98 & $\mathrm{R}^{2}=0.9540$ \\
\hline & $\mathrm{AA} \& \mathrm{BC}^{a}$ & 0.98 & $\mathrm{R}^{2}=0.9571$ \\
\hline & $\mathrm{AA} \& \mathrm{TPC}^{a}$ & 0.96 & $\mathrm{R}^{2}=0.9277$ \\
\hline & $\mathrm{TPC} \& \mathrm{BX}^{a}$ & 0.99 & $\mathrm{R}^{2}=0.9877$ \\
\hline & $\mathrm{TPC} \& \mathrm{BC}^{a}$ & 0.99 & $\mathrm{R}^{2}=0.9883$ \\
\hline & $\mathrm{BX}(\mathrm{WE}) \& \mathrm{BX}(\mathrm{EWE})^{a}$ & 0.99 & $\mathrm{R}^{2}=0.9944$ \\
\hline & $\mathrm{BC}(\mathrm{WE}) \& \mathrm{BC}(\mathrm{EWE})^{a}$ & 0.99 & $\mathrm{R}^{2}=0.9889$ \\
\hline & $\mathrm{TPC}(\mathrm{WE}) \&$ TPC $(\mathrm{EWE})^{a}$ & 0.99 & $\mathrm{R}^{2}=0.9886$ \\
\hline & $\mathrm{AA}(\mathrm{WE}) \& \mathrm{AA}(\mathrm{EWE})^{a}$ & 0.97 & $\mathrm{R}^{2}=0.9421$ \\
\hline
\end{tabular}

Different superscript letters mean significant differences $(p<0.001)$ 


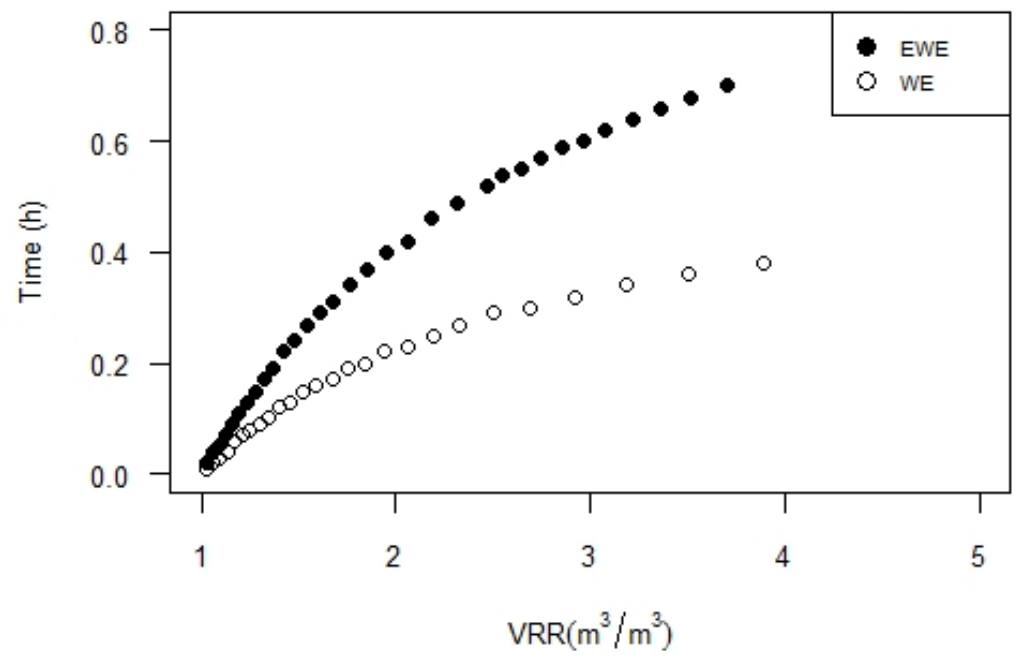

Figure 6: Variation of processing time with volume reduction ratio (VRR) during the concentration process by nanomembrane type NF 200

$\mathrm{mg} \cdot \mathrm{L}^{-1}$ (phenolic), and $199.70 \pm 3.28 \mathrm{mg} \cdot \mathrm{L}^{-1}$ (antiradical activity). Since extraction processes were executed at low temperature and short extraction time with mild solvent concentration, the efficiency of the solvent was not significant enough to acquire greater outputs (Sawicki et al., 2016). As active hydrophilic compounds, water seems to be more operative to extract these desired compounds than alcoholic solvents in some cases (Bastos \& Gonçalves, 2017).

With high water affinity, betalains and phenolic compounds extraction can mostly be fulfilled by pure water; however, changes in polarity of the solvent by combining with alcohols are also beneficial to accomplish the extraction performance. This can assist in overcoming the disturbance of water-soluble proteins some point which leads to enhancing the recovery of targeted compounds via membrane separation (Delgado-Vargas et al., 2000; Strack et al., 2003).

The amounts of betacyanin compounds were higher in both extracts than betaxanthin since the first compound is more stable in process- ing than the second one (Bastos \& Gonçalves, 2017). Based on the investigation of Nemzer et al. (2011), the ratio of the violet colour compound to that of yellow fundamentally differs along with the varieties of beetroot and processing conditions, albeit the amount of the former compound was always superior compared to the latter one. To achieve homogeneity of raw materials, ground peels were blended prior to extraction; however, the contrast in the amount of these compounds might be attributed to the genotype of raw material and season of harvesting (Chong et al., 2014; Sawicki et al., 2016; Stintzing et al., 2005).

Figure 2 represents betalain concentrations as a function of volume reduction ratio (VRR). As depicted in the figure, all trends of concentration ratio for colour compounds were similar in both extracts. Concentration ratios of betaxanthin (BX) and betacyanin (BC) which were achieved in ethanol-water extract (EWE) were 4.5, while a maximum of 4 was attained in water extract (WE). For TPC, trends of concentration ratio 
(3.7) for both extracts were comparable (Figure 3). On the other hand, drastic changes in the concentration ratio of antiradical activity were not shown in water extract displaying the maximum value of 2.6 even though aqueous ethanol could be concentrated up to 3.7 (Figure 4).

The concentration ratios of all desired compounds in ethanol-water retentates surpassed pure water, implying that nanofiltration is more satisfactory for the concentration of aqueous ethanol extract than pure water extract. However, a longer filtration process was required in aqueous ethanol extract, which led to lower flux than pure water. This observation was in accordance with Kim et al. (2002), who observed higher flux in water than in alcoholic solvents as they deduced that differences in molecular weight, dielectric constant, surface tension and viscosity of the solvents have some influence on permeate flux. According to Chong et al. (2014), water can extract the desired compounds with less impurity than alcoholic solvents. The formation of a polymerized layer on the surface of the membrane can also bring a drop in permeate flux, considering that this layer is the effluence of retentate concentration (Jiraratananon \& Chanachai, 1996). Bolton et al. (2006) added that flux decline occurs in biotech process stream filtration as a consequence of the accumulation of foulants which creates a cake layer on membranes and causes complete blocking. The amounts of betaxanthin, betacyanin, phenolic, and antioxidants retained in the final aqueous ethanol extract were $206.62 \pm 1.37 \mathrm{mg} \cdot \mathrm{L}^{-1}$, $339.72 \pm 2.89 \mathrm{mg} \cdot \mathrm{L}^{-1}, 972.72 \pm 47.49 \mathrm{mg} \cdot \mathrm{L}^{-1}$, and $745.97 \pm 25.45 \mathrm{mg} \cdot \mathrm{L}^{-1}$ respectively.

Figures 5 and 6 typify changes of permeate flux values and processing time with the volume reduction ratio during the concentration process. As interpreted in Figure 5, the permeate flux of ethanol-water extract was considerably lower than that of water extract. Both methods, initially, showed a rapid decrease in permeate flux; yet flux declining rate became almost steady after approximately 12 minutes of processing time. Severe initial fouling is always exhibited in a fresh membrane when TMP is fixed for the whole operation (Miller et al., 2014). Comparatively, the rejection rate is elevated above the threshold flux up to a considerable accumulation of foulants on the membrane surface (Miller et al., 2014). Along with elevated processing time, the volume reduction ratio improved (Figure 6). The resistance in transport manipulates the processing time, causing permeate flux decline (Miller et al., 2014). In our work, the interference of foulants with the membrane was found to be strong in water extract, which exhibits higher fouling resistance of membrane than aqueous ethanol and even membrane resistance to transport. As discussed earlier, leaching out of some hydrophilic compounds by pure water is more productive than the solvent action, which in turn might be responsible for membrane efficiency reduction. According to Al-Amoudi (2010), natural organic matter like phenolic (aromatic) groups have distinct effects on membrane fouling thereby inducing reversible and irreversible permeate flux decline. Membrane retention for betalains, phenolic, and antioxidant activity was assumed to be $99 \%$ hence they were not detectable in the permeate of either extract. From the regression analysis and the correlational test between the targeted compounds (Table 2), it can be seen that colour compounds and total phenolic compounds detected in each extract are highly correlated ( $\mathrm{R}^{2}$ greater the 0.92 in all cases) with strong antiradical activity. Besides, the significant level within and between water and ethanolwater extracts for beetroot peel was less than 0.001 for each parameter, i.e, betalains, phenolic compounds, and antioxidant activity.

\section{Conclusions}

Our study showed that a nanofiltration membrane can successfully concentrate beetroot peel juice owing to the considerable amounts of betalains and polyphenols exhibiting desirable antiradical activity, which were in the final retentates as compared to the crude extracts. Since consumers' attention has shifted to safety concerns, the application of phytochemicals in functional food processing instead of synthetic food additives can be expected to thrive. For this reason, our experiment could be helpful to extend the application of membrane filtration processes for the recovery of these valuable compounds from agro-industrial wastes such as beetroot peel, al-

IJFS | October 2021 | Volume $10 \mid$ pages 334-345 
beit, some challenges, such as membrane fouling and its consequence of washing and maintaining costs, need to be taken into consideration.

\section{Acknowledgements}

This work was financially supported by the European Union and the European Social Fund (grant agreement no.EFOP-3.6.3-VEKOP-162017-00005), Tempus Public Foundation, under the Stipendium Hungaricum Scholarship Program. We appreciate the Doctoral School of Food Science, Hungarian University of Agriculture and Life Sciences for the support to accomplish the work as well.

\section{References}

Al-Amoudi, A. S. (2010). Factors affecting natural organic matter (NOM) and scaling fouling in NF membranes: A review. Desalination, 259(1-3), 1-10. https://doi. org/10.1016/j.desal.2010.04.003

Arend, G. D., Adorno, W. T., Rezzadori, K., Di Luccio, M., Chaves, V. C., Reginatto, F. H., \& Cunha Petrus, J. C. (2017). Concentration of phenolic compounds from strawberry (Fragaria $X$ ananassa Duch) juice by nanofiltration membrane. Journal of Food Engineering, 201, 36-41. https: / / doi .org / 10.1016/j . jfoodeng. 2017.01 .014

Banvolgyi, S., Horvath, S., Stefanovits-Banyai, E., Bekassy-Molnar, E., \& Vatai, G. (2009). Integrated membrane process for blackcurrant (Ribes nigrum L.) juice concentration [3rd Membrane Science and Technology Conference of Visegrad Countries (PERMEA 2007), Siofok, HUNGARY, SEP 02-06, 2007]. Desalination, 241(1-3), 281-287. https://doi. org/10.1016/j.desa1.2007.11.088

Banvolgyi, S., Kiss, I., Bekassy-Molnar, E., \& Vatai, G. (2006). Concentration of red wine by nanofiltration [2nd Membrane Science and Technology Conference of Visegrad Countries (PERMEA 2005), Polanica Zdrol, POLAND, SEP 18-22, 2005]. Desalination, 198(1-3), 8-
15. https://doi.org/10.1016/j.desal. 2006.09.003

Bastos, E. L., \& Gonçalves, L. C. P. (2017). Chapter 9 - Microwave-Assisted Extraction of Betalains. In H. Dominguez González \& M. J. González Muñoz (Eds.), Water extraction of bioactive compounds (pp. 245-268). Elsevier. https : / / doi .org / 10.1016 / B978- 0- 12 809380-1.00009-7

Benzie, I. F. F., \& Strain, J. J. (1996). The ferric reducing ability of plasma (frap) as a measure of "antioxidant power": The frap assay. Analytical Biochemistry, 239(1), 70-76. https://doi.org/10.1006/ abio.1996.0292

Bolton, G., LaCasse, D., \& Kuriyel, R. (2006). Combined models of membrane fouling: Development and application to microfiltration and ultrafiltration of biological fluids. Journal of Membrane Science, 27r(1-2), 75-84. https: / / doi .org / 10 . 1016/j.memsci.2004.12.053

Bucur, L., Taralunga, G., \& Schroder, V. (2016). The Betalains Content and Antioxidant Capacity of Red Beet (Beta vulgaris L. subsp vulgaris) Root. Farmacia, 64(2), 198-201.

Chong, P. H., Yusof, Y. A., Aziz, M. G., Chin, N. L., Syed Muhammad, S. K., et al. (2014). Evaluation of solvent extraction of amaranth betacyanins using multivariate analysis. International Food Research Journal, 21(4).

Dach, H. (2008). Comparison of nanofiltration and reverse osmosis processes for a selective desalination of brackish water feeds (Doctoral dissertation). Université d'Angers.

Delgado-Vargas, F., Jimenez, A. R., \& ParedesLopez, O. (2000). Natural pigments: Carotenoids, anthocyanins, and betalains - characteristics, biosynthesis, processing, and stability. Critical Reviews in Food Science and Nutrition, 40(3), 173-289. https : / / doi .org / 10.1080 / 10408690091189257

dos Santos, C. D., Scherer, R. K., Cassini, A. S., Ferreira Marczak, L. D., \& Tessaro, I. C. (2016). Clarification of red beet stalks 
extract by microfiltration combined with ultrafiltration. Journal of Food Engineering, 185, 35-41. https://doi.org / 10.1016/j.jfoodeng.2016.03.031

Elbandy, M. A., \& Abdelfadeil, M. G. (2008). Stability of betalain pigments from red beetroot (Beta vulgaris). Egyptian Journal Food Science, 36, 49-60.

Ghosh, P., Pradhan, R. C., Mishra, S., \& Rout, P. K. (2018). Quantification and concentration of anthocyanidin from indian blackberry (jamun) by combination of ultra- and nano-filtrations. Food and Bioprocess Technology, 11(12), 21942203. https: / / doi.org/10.1007/s11947018-2176-4

Hussain, E. A., Sadiq, Z., \& Zia-Ul-Haq, M. (2018). Betalains: Biomolecular aspects. Springer.

Jiraratananon, R., \& Chanachai, A. (1996). A study of fouling in the ultrafiltration of passion fruit juice. Journal of Membrane Science, 111(1), 39-48. https://doi.org/ 10.1016/0376-7388(95)00270-7

Kale, R., Sawate, A., Kshirsagar, R., Patil, B., \& Mane, R. (2018). Studies on evaluation of physical and chemical composition of beetroot (Beta vulgaris L.) Int $J$ Clin Sci, 6(2), 2977-79.

Kavalcová, P., Bystrická, J., Tomáš, J., Karovičová, J., Kovarovič, J., \& Lenková, M. (2015). The content of total polyphenols and antioxidant activity in red beetroot. Potravinarstvo Slovak Journal of Food Sciences, 9(1), 77-83. https://doi.org/10.5219/441

Kim, I. C., Jegal, J., \& Lee, K. H. (2002). Effect of aqueous and organic solutions on the performance of polyamide thin-film-composite nanofiltration membranes. Journal of Polymer Science Part B-Polymer Physics, 40(19), 2151-2163. https://doi.org/10.1002/polb.10265

Koczka, N., Stefanovits-Bányai, É., \& Ombódi, A. (2018). Total polyphenol content and antioxidant capacity of rosehips of some rosa species. Medicines, 5(3), 84.

Kujala, T., Loponen, J., \& Pihlaja, K. (2001). Betalains and phenolics in red beetroot (Beta vulgaris) peel extracts: Ex- traction and characterisation. Zeitschrift Fur Naturforschung C-a Journal of Biosciences, 56 (5-6), 343-348.

Liu, M., Lu, Z., Chen, Z., Yu, S., \& Gao, C. (2011). Comparison of reverse osmosis and nanofiltration membranes in the treatment of biologically treated textile effluent for water reuse. Desalination, 281, 372-378. https://doi.org/10.1016/ j.desal.2011.08.023

Maran, J. P., \& Priya, B. (2016). Multivariate statistical analysis and optimization of ultrasound-assisted extraction of natural pigments from waste red beet stalks. Journal of Food Science and TechnologyMysore, 53(1), 792-799. https:// doi. org/10.1007/s13197-015-1988-8

Miguel, M. G. (2018). Betalains in Some Species of the Amaranthaceae Family: A Review. Antioxidants, 7(4). https:// doi. org/10.3390/antiox7040053

Miller, D. J., Kasemset, S., Paul, D. R., \& Freeman, B. D. (2014). Comparison of membrane fouling at constant flux and constant transmembrane pressure conditions. Journal of Membrane Science, 454, 505-515. https://doi.org/10.1016/ j.memsci.2013.12.027

Mironczuk-Chodakowska, I., Witkowska, A. M., \& Zujko, M. E. (2018). Endogenous non-enzymatic antioxidants in the human body. Advances in Medical Sciences, 63(1), 68-78. https://doi.org/ 10.1016/j.advms.2017.05.005

Nemzer, B., Pietrzkowski, Z., Sporna, A., Stalica, P., Thresher, W., Michalowski, T., \& Wybraniec, S. (2011). Betalainic and nutritional profiles of pigment-enriched red beet root (Beta vulgaris L.) dried extracts. Food Chemistry, 127(1), 42-53. https: / / doi.org/10.1016/j. foodchem. 2010.12 .081

Perfilov, V. (2018). Mathematical modelling of membrane separation processes.

Sawicki, T., Baczek, N., \& Wiczkowski, W. (2016). Betalain profile, content and antioxidant capacity of red beetroot dependent on the genotype and root part. Journal of Functional Foods, 27, 249- 
261. https://doi.org/10.1016/j.jff.2016. 09.004

Sawicki, T., \& Wiczkowski, W. (2018). The effects of boiling and fermentation on betalain profiles and antioxidant capacities of red beetroot products. Food Chemistry, 259, 292-303. https://doi.org/10. 1016/j.foodchem.2018.03.143

Shahidi, F., \& Ambigaipalan, P. (2015). Phenolics and polyphenolics in foods, beverages and spices: Antioxidant activity and health effects-a review. Journal of Functional Foods, 18(B), 820-897. https:// doi.org/10.1016/j.jff.2015.06.018

Stintzing, F. C., Herbach, K. M., Mosshammer, M. R., Carle, R., Yi, W. G., Sellappan, S., Akoh, C. C., Bunch, R., \& Felker, P. (2005). Color, betalain pattern, and antioxidant properties of cactus pear ( $O p$ untia spp.) clones. Journal of Agricultural and Food Chemistry, 53(2), 442451. https://doi.org/10.1021/jf048751y

Strack, D., Vogt, T., \& Schliemann, W. (2003). Recent advances in betalain research. Phytochemistry, 62(3), 247-269. https: / / doi . org / 10 . 1016 / S0031 - 9422(02 ) 00564- 2

Vladisavljevic, G. T., Vukosavljevic, P., \& Bukvic, B. (2003). Permeate flux and fouling resistance in ultrafiltration of depectinized apple juice using ceramic membranes. Journal of Food Engineering, 60(3), 241-247. https://doi.org/10. 1016/S0260-8774(03)00044-X

Vulic, J. J., Cebovic, T. N., Canadanovic, V. M., Cetkovic, G. S., Djilas, S. M., Canadanovic-Brunet, J. M., Velicanski, A. S., Cvetkovic, D. D., \& Tumbas, V. T. (2013). Antiradical, antimicrobial and cytotoxic activities of commercial beetroot pomace. Food and Function, 4(5), 713-721. https : / / doi.org / 10.1039/ c3fo30315b

Zin, M. M., Marki, E., \& Banvolgyi, S. (2020). Conventional extraction of betalain compounds from beetroot peels with aqueous ethanol solvent. Acta Alimentaria, 49(2), 163-169. 